\title{
legelivet
}

På disse sidene i Tidsskriftet - legelivet - finner du stoff om legers liv.

Her er det presentasjon av arbeidssteder, nyhetssaker, nye doktorgrader,

nye spesialister og minneord. Alt samlet på ett sted - så du kan følge enda bedre med.

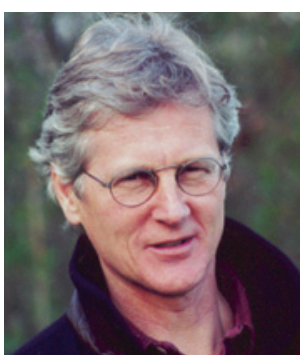

Karl Otto Nakken Foto: Privat

Karl Otto Nakken (f. 1945) er pensjonert nevrolog. Han har i over 35 år vært ansatt ved Spesialsykehuset for epilepsi (SSE) i Sandvika.

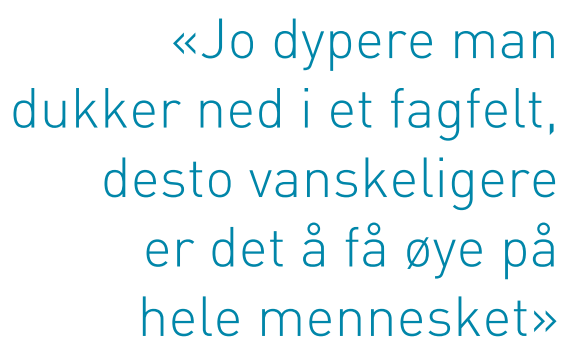

«Jo dypere man esto vanskeligere renty hele-mennesket»

\section{Stadig økende kvistspesialisering}

I medisinen er det blitt en økende tendens til ikke bare subspesialisering, men også subsubspesialisering.

Om vi fastholder analogien med treet, der medisinen utgjør stammen og spesialitetene grenene, har vi de senere år sett en utvikling mot stadig flere kvistspesialister. Enkelte av kvistene er tynne og kan synes å befinne seg svært langt fra stammen.

Etter mitt skjønn er treanalogien dårlig. De som sitter ytterst på treet, burde ha den beste oversikten. Slik er det ikke. Jo dypere man dukker ned i et fagfelt, desto vanskeligere er det å få øye på hele mennesket.

Eksempelvis har vi innen øre-nese-halsfaget fått laryngologer, innen endokrinologien diabetologer, innen kardiologien arytmologer, innen gastrologien hepatologer, og innen voksen- og barnenevrologien har vi fått epileptologer. Innenfor dette feltet igjen har vi fătt enkelte absensologer - som ofte er fraværende. På en egen kvist sitter de nevrofysiologiske epileptologene som daglig leter etter skarp aktivitet i EEG-kurven. De hevder å være de eneste som virkelig kan påberope seg spisskompetanse.

For en tid tilbake spurte jeg en kollega fra basalfagene om han ville komme på vårt fredagsmøte på epilepsisykehuset og forelese om glutamatreseptorer. Han virket både overrasket og noe oppgitt over at jeg kunne spørre så dumt. Jeg forsto straks at temaet var altfor omfattende. Han mente jeg måtte være langt mer spesifikk: hvilke av reseptorene ønsket jeg at han skulle snakke om?

Jeg tenker det er godt at vi fortsatt har noen generalister, det vil si allmennpraktiserende kolleger som i møte med pasienter evner å se hele mennesket, altså noe lenger enn til synapser og mitokondrier.

I doktorklubben har vi en gastrokirurg. Han har viet mye av sitt legeliv til sykdommer i kaudale deler av tarmen. Likevel misliker han at vi kaller ham proktolog. I bestemte ordelag har han latt oss forstå at han heller ikke er fremmed for sykdommer lenger opp i tarmtraktus. Dessuten at han med årene var blitt en erfaren skopør. I en sen nattetime røpet han at han i mange år hadde gått med en ikke lenger så hemmelig drøm om å bli den første som utfører en transrektal tonsillektomi.

\section{Karl Otto Nakken}

karln@ous-hf.no 